\title{
A Research to Determine the Ethical Climate Perception of Nurses Who Work In Private Hospitals
}

\author{
Emel AVÇİN ${ }^{1}$, Şeyda CAN ${ }^{2}$, Beyza ERKOÇ ${ }^{3}$, Fatma YEŞİL ${ }^{4}$, Gürkan ERDOĞAN $^{5}$
}

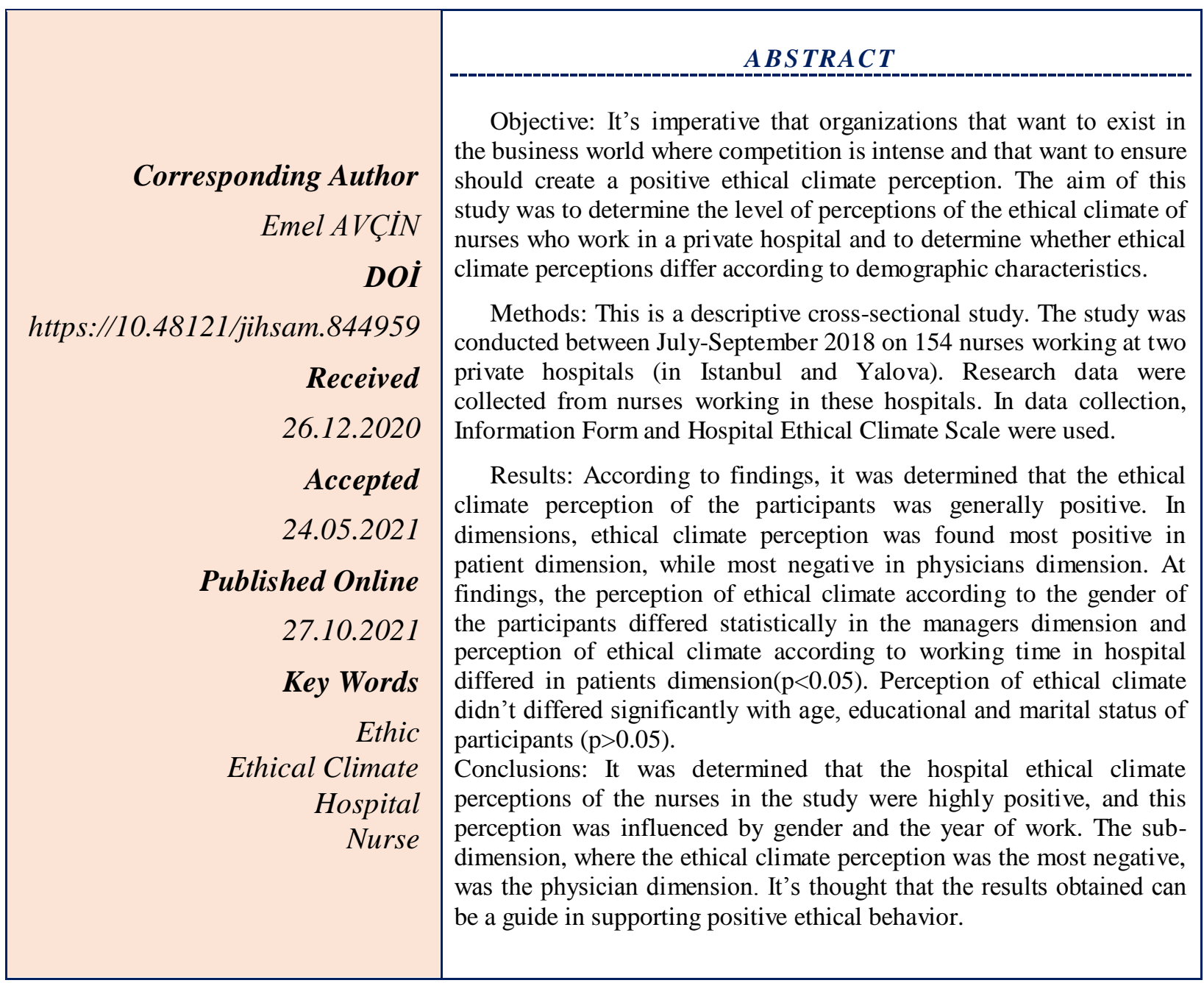

${ }^{1}$ Yalova University, Thermal Vocational School of Higher Education Gökçedere Cad, 77400, Yalova /Turkey e- posta: leylifer02@gmail.com / Orcid: 0000-0002-8867-4039

$2 \mathrm{PhD}$, Assistant Professor Yalova University, Faculty of Health Sciences Gökçedere Cad, 77400, Yalova /Turkey E- mail: seyda.cann@ hotmail.com / Orcid: 0000-0001-9733-133X

$3 \mathrm{PhD}$, Assistant Professor Bülent Ecevit University, Faculty of Health Sciences Esenköy, Kozlu, 67600 Zonguldak/Turkey E- mail: beyzahatipoglu@ @indowslive.com / Orcid Number: https://orcid.org/0000-0002- 0035-6782

${ }^{4}$ Lecture Yalova University, Thermal Vocational School of Higher Education Gökçedere Cad, 77400, Yalova /Turkey E- mail: yesilhalic1985 @ hotmail.com / Orcid Number: https://orcid.org/0000-0002-8867-4039

5 Lecture Yalova University, Thermal Vocational School of Higher Education Gökçedere Cad, 77400, Yalova /Turkey E- mail: gurkan_erdogan@ hotmail.com / Orcid Number: https://orcid.org/0000-0002-2517-0677 
Most of the today's enterprises are trying to integrate ethical understanding with all the activities of the organization. For that purpose, the enterprises try to continue their activities in accordance with the laws, regulations and the traditions of the society to which they serve (Ay et al., 2009). Within the last years, the scandals of the organizations and the lapses in corporate ethical behaviors have increased the awareness regarding the importance of the ethical climate (DeConinck, 2011). The progresses in information and communication technologies have enabled the individuals to have quicker access to information, better follow-up of the organizations and increase of the information sharing. This has caused all the shareholders, particularly the customers and the employees, to access to information and to react to the problems within the organizations very quickly. Thus, creating a positive ethical climate perception has become a must for the organizations seeking to exist and ensure sustainability within the business environment where the competition is intense.

The financial problems and pressures in the delivery of the healthcare services have confronted healthcare institutions with business-oriented ethical issues (Silverman, 2000). The creation of a favorable working environment and a positive ethical climate has also become very important for the hospitals in order to ensure high professional performance, increase the quality of the healthcare outcomes and provide sufficient medical care and nursing services to the patients (Shafipour et al., 2016).

Ethical climate is defined as a type of work climate that is best understood as a group of prescriptive climates reflecting the organizational procedures, policies, and practices with moral consequences (Martin and Cullen, 2006). According to a definition from the perspective of health institutions, ethical climate is "the organizational conditions and practices that affect the way difficult patient care problems, with ethical complications, are discussed and decided"
(Hart, 2005).The ethical climate of hospitals is typical of the organizational atmosphere comprising of the interpersonal relations among the health care personnel as well as their relationships with patients and their families (Shafipour et al., 2016).

Ethical climate is the shared perception of what is allowed and what is prohibited regarding the moral issues within the organization (Fein et al., 2013). Ethical climates have many functions in the organizations. They help the employees by answering the question "What should I do?" when they encounter an ethical problem. Besides, ethical climates also help the employees by determining the ethical issues in the organization. In other words, ethical climates serve as a perceptive lens by serving the employees to identify and evaluate the issues (Cullen et al., 2003). The establishment of the ethical climate in an organization depends on the demonstration of the appreciation of ethical values by the management of the organization through their general policies and actions. The ethical sensitivity of the management will encourage the lower-level employees to adopt the ethical standards (Bahcecik and Öztürk, 2003).

The perception of ethical climate has either direct or indirect effect on both health sector and various sectors. When analyzed the researches in the literature, ethical climate perception has been found out to be correlated with job satisfaction, organizational commitment (Schwepker, 2001; Nafei, 2015), exhaustion (Çetinet al., 2015), job stress (Sert et al., 2014), turnover intention (Allari, 2016; Shafipour et al., 2016), organizational confidence, individual performance (Büte, 2011), financial performance and customer satisfaction (Moon and Choi, 2014).

The aim of this study was to determine the level of perceptions of the ethical climate of nurses who work in a private hospital and to determine whether ethical climate perceptions differ according to demographic characteristics.

\section{MATERIALS AND METHODS}

\section{Study Aim and Design}

The aim of this study was to determine the level of perceptions of the ethical climate of nurses who work in a private hospital and to determine whether ethical climate perceptions differ according to demographic characteristics. Results to be obtained are believed to serve as data for the fields of nursing practices and training. This is a descriptive (cross-sectional) study carried out to identify level of perceptions of the ethical climate of nurses.

\section{Sample}

The population of the study consists of 240 nurses working at two private hospitals in Turkey between July 2018-September 2018. One of these hospitals operates in Istanbul and other in Yalova. Two different hospitals in these two different cities in the Marmara region were included in the study due to reasons such as the larger population size of the population served and the fact that one of the cities is a metropolitan city. Research data were collected from nurses who work in these hospitals. The study was carried out with 154 nurses (91 from Istanbul and 63 
from Yalova) who agreed to participate in the study upon being informed about the study, its aim, content and method.

The data were collected by face to face interviews with individuals and verbal permission was obtained from individuals.

Sample selection criteria of the study:

$>$ Working at the relevant institution as a nurse for at least one year,

$>$ Volunteering to participate in the study.

\section{Study Questions}

Q1: What is the demographic characteristics of nurses?

Q2: What is the level of ethical climate perceptions of nurses?

Q3:Is there any relationship between ethical climate perceptions and demographic characteristics of nurses?

\section{Data Collection Tools}

In data collection, Information Form and Hospital Ethical Climate Scale were used. The questionnaire used in the research consists of two parts. In the first part, questions are asked to determine the demographic characteristics of the participants. In the second part, there are statements about the determination of ethical climate perceptions of the participants.

Information form: Questioning the introductory characteristics, the form consists of 5 questions aiming to identify the demographic characteristics (age, gender, marital status of nurses), socioeconomic characteristics (level of education), professional characteristics (total duration of work in the profession).
Hospital Ethical Climate Scale (HECS): "Hospital Ethical Climate Survey", which developed by Olson (1998), was used. Turkish validity and reliability study of the scale was performed by Bahcecik and Öztürk (2003). The scale consists of five dimensions and a total of 26 items: Peers (4 items), Patients (4 items), Managers (6 items), Hospital (6 items) and Physicians (6 items). The expressions in the scale are measured by the 5-point Likert scale. The lowest score to be taken from HESC is 26, and the highest score is 130 . The increase in the total score obtained from the scale indicates that the perception of the hospital ethical climate has increased positively. Olson (1998) found the scale's Cronbach alpha value of 0.91, while Bahçecik and Öztürk (2003) found it to be 0.89 .According to this result, the reliability of the scale was found to be high. In our study, the Cronbach's Alpha value of the scale was found to be 0.75 .

\section{Data Analysis}

SPSS 18.0 statistical package program was used in the analysis of the obtained data. Descriptive statistics were calculated to determine the distribution of demographic characteristics. Compliance with normal distribution was tested through the KolmogorovSmirnov test. The result of the test showed that the data did not come from normal distribution $(\mathrm{p}<0.05)$. Therefore, Mann Whitney- $U$ test was used to compare two independent groups. The findings were evaluated at $95 \%$ confidence interval and 5\% significance level.

\section{Ethical Aspect}

This study was carried out upon the permissions of the Ethics Committee of Non-Interventional Research (Decision No: 2018-12/6) and of the provincial directorate of health. The "Informed Permission Form for Volunteers", prepared by the researchers to inform the participants, was adopted in the study, in every step of which ethical principles were observed.

\section{RESULTS}

Findings Related to Demographic

\section{Characteristics of Nurses}

Table 1 shows the demographic information of the participants. $123(79.9 \%)$ were female and $31(20.1 \%)$ were male. When the distribution of the participants in the age ranges was examined, 90 participants $(58.4 \%)$ were in 25 years or younger and 64 participants $(41.6 \%)$ were in 26 years or older. 103 participants
$(66.9 \%)$ have associate's degree or lower degree and while $51(33.1 \%)$ had bachelor's degree. 79 of total participants $(51.3 \%)$ were single and $75(48.7 \%)$ were married. Looking at the length of work of the participants in the hospital where the study was conducted, it was determined that 120 participants (77.9\%) worked for 5 years or less and 34 participants $(22.1 \%)$ for 6 years or more. 
Table 1. Distribution of Demographic Characteristics (N:154)

\begin{tabular}{lrc}
\hline Variables & Frequency & Percentage \\
\hline Gender & & \\
Female & 123 & 79.9 \\
Male & 31 & 20.1 \\
\hline Age & & \\
$\leq 25$ Years & 90 & 58.4 \\
$\geq 26$ Years & 64 & 41.6 \\
\hline Educational Status & & \\
Associate's Degree or Lower Degree & 103 & 66.9 \\
Bachelor's Degree & 51 & 33.1 \\
\hline Marital Status & & \\
Single & 79 & 51.3 \\
Married & 75 & 48.7 \\
\hline Work Time in Hospital & & \\
$\leq 5$ Years & 120 & 77.9 \\
$\geq 6$ Years & 34 & 22.1 \\
\hline
\end{tabular}

\section{Findings Related to the Hospital Ethical Climate of Nurses}

According to Table 2, participants' perception of ethical climate was generally positive (3.57 \pm 0.34$)$. In dimensions, ethical climate perception was found most positive in patients dimension (3.94 \pm 0.49$)$, while most negative in physicians dimension $(3.10 \pm 0.55)$.

Table 2. Hospital Ethical Climate Scale (with subscales) (N:154)

\begin{tabular}{l|lll}
\hline Variable & n & Mean & SD \\
\hline Peers & 154 & 3.85 & 0.52 \\
Patients & 154 & 3.94 & 0.49 \\
Managers & 154 & 3.55 & 0.62 \\
Hospital & 154 & 3.63 & 0.48 \\
Physicians & 154 & 3.10 & 0.55 \\
\hline Perception of Ethical Climate & $\mathbf{1 5 4}$ & $\mathbf{3 . 5 7}$ & $\mathbf{0 . 3 4}$ \\
\hline
\end{tabular}

\section{Findings Related To Comparison Of Ethical Climate Perception By Sociodemographic Characteristics Of} The Nurses

Table 3 shows the comparison of ethical climate perception level according to the demographic characteristics of the participants. According to the table, it was determined that the level of ethical climate perception related to managers dimension was statistically different according to gender $(p<0.05)$. This difference is attributed to the fact that female participants' perception of ethical climate is more positive than male participants. The ethical climate perception level was not statistically different in other dimensions ( $\mathrm{p}>0.05)$.

Table 3 presents the comparison of the ethical climate perception level of the participants according to the working time in the hospital. The level of ethical climate perception in the patients dimension differed statistically according to the working time in the hospital $(\mathrm{p}<0.05)$. This difference was attributed to the fact that the participants working in the hospital for 5 years or less were more positive about the ethical climate perception of the patients than the participants who worked in the hospital for 6 years or more. The ethical climate perception level of the other dimensions was not statistically different according to the working time in the hospital $(\mathrm{p}>0.05)$.

According to the age, educational status and marital status of the participants, the level of ethical climate perception was not statistically different $(\mathrm{p}>0.05)$. 
Table 3. Comparison Of Ethical Climate Perception By Sociodemographic Characteristics.

\begin{tabular}{|c|c|c|c|c|c|c|c|c|c|c|c|c|}
\hline \multicolumn{3}{|c|}{ DIMENSIONS } & \multicolumn{2}{|c|}{ Peers } & \multicolumn{2}{|c|}{ Patients } & \multicolumn{2}{|c|}{ Managers } & \multicolumn{2}{|c|}{ Hospital } & \multicolumn{2}{|c|}{ Physicians } \\
\hline \multicolumn{2}{|l|}{ Variables } & n & $\operatorname{Mean} \pm$ SD & $\mathbf{U} / \mathbf{p}$ & Mean \pm SD & U/p & $\operatorname{Mean} \pm$ SD & $\mathbf{U} / \mathbf{p}$ & Mean \pm SD & $\mathbf{U} / \mathbf{p}$ & Mean \pm SD & $\mathbf{U} / \mathbf{p}$ \\
\hline \multirow[t]{2}{*}{ Gender } & Female & 123 & $3.87 \pm 0.54$ & \multirow{2}{*}{$\begin{array}{r}1,723 \\
0.40\end{array}$} & $3.91 \pm 0.51$ & 1,528 & $3.62 \pm 0,64$ & \multirow{2}{*}{$\begin{array}{l}1,437 \\
0.03 *\end{array}$} & $3.64 \pm 0.51$ & \multirow{2}{*}{$\begin{array}{r}1,705 \\
0.36\end{array}$} & $3.13 \pm 0.59$ & \multirow{2}{*}{$\begin{array}{r}1,7330 \\
.43\end{array}$} \\
\hline & Male & 31 & $3.78 \pm 0.45$ & & $4.06 \pm 0,38$ & 0.08 & $3.29 \pm 0,48$ & & $3.57 \pm 0.34$ & & $2.99 \pm 0.30$ & \\
\hline \multirow{2}{*}{ Age } & $\leq 25$ Years & 90 & $3.85 \pm 0.54$ & \multirow{2}{*}{$\begin{array}{c}2,878 \\
1.00\end{array}$} & $3.97 \pm 0.50$ & 2,742 & $3.57 \pm 0.67$ & \multirow{2}{*}{$\begin{array}{r}2,878 \\
0.99\end{array}$} & $3.61 \pm 0.50$ & \multirow[t]{2}{*}{$\begin{array}{c}2,8600 \\
.94\end{array}$} & $3.07 \pm 0.61$ & \multirow{2}{*}{$\begin{array}{r}2,5410 \\
.21\end{array}$} \\
\hline & $\geq 26$ Years & 64 & $3.86 \pm 0.50$ & & $3.91 \pm 0.47$ & 0.61 & $3.53 \pm 0.56$ & & $3.65 \pm 0.45$ & & $3.15 \pm 0.46$ & \\
\hline \multirow{2}{*}{$\begin{array}{l}\text { Educational } \\
\text { Status }\end{array}$} & $\begin{array}{l}\text { Associate's } \\
\text { Degree or } \\
\text { Lower }\end{array}$ & 103 & $3.88 \pm 0.52$ & \multirow[t]{2}{*}{$\begin{array}{c}2,388 \\
0.35\end{array}$} & $3.94 \pm 0.49$ & \multirow{2}{*}{$\begin{array}{r}2,539 \\
0.73\end{array}$} & $3.53 \pm 0.58$ & \multirow{2}{*}{$\begin{array}{r}2,595 \\
0.90\end{array}$} & $3.63 \pm 0.47$ & \multirow[t]{2}{*}{$\begin{array}{c}2,4870 \\
.59\end{array}$} & $3.06 \pm 0.49$ & \multirow{2}{*}{$\begin{array}{r}2,3150 \\
.23\end{array}$} \\
\hline & $\begin{array}{l}\text { Bachelor's } \\
\text { Degree }\end{array}$ & 51 & $3.80 \pm 0.52$ & & $3.96 \pm 0.49$ & & $3.59 \pm 0.71$ & & $3.62 \pm 0.49$ & & $3.18 \pm 0.65$ & \\
\hline \multirow{2}{*}{$\begin{array}{l}\text { Marital } \\
\text { Status }\end{array}$} & Single & 79 & $3.86 \pm 0.49$ & \multirow{2}{*}{$\begin{array}{c}2,855 \\
0.69\end{array}$} & $3.99 \pm 0.53$ & 2618 & $3.61 \pm 0.67$ & \multirow{2}{*}{$\begin{array}{r}2,745 \\
0.43\end{array}$} & $3.61 \pm 0.51$ & \multirow{2}{*}{$\begin{array}{c}2,9600 \\
.99\end{array}$} & $3.08 \pm 0.59$ & \multirow{2}{*}{$\begin{array}{r}2,8620 \\
.72\end{array}$} \\
\hline & Married & 75 & $3.84 \pm 0.56$ & & $3.90 \pm 0.44$ & 0.21 & $3.49 \pm 0.56$ & & $3.64 \pm 0.44$ & & $3.12 \pm 0.51$ & \\
\hline \multirow{2}{*}{$\begin{array}{l}\text { Work Time } \\
\text { in Hospital }\end{array}$} & $\leq 5$ Years & 120 & $3.87 \pm 0.51$ & \multirow{2}{*}{$\begin{array}{c}1,843 \\
0.38\end{array}$} & $3.99 \pm 0.50$ & 1,585 & $3.55 \pm 0.62$ & \multirow{2}{*}{$\begin{array}{r}1,961 \\
0.73\end{array}$} & $3.60 \pm 0.46$ & \multirow{2}{*}{$\begin{array}{c}1,778 \\
0.25\end{array}$} & $3.07 \pm 0.55$ & \multirow{2}{*}{$\begin{array}{r}1,769 \\
0.23\end{array}$} \\
\hline & $\geq 6$ Years & 34 & $3.79 \pm 0.55$ & & $3.79 \pm 0.42$ & & $3.56 \pm 0.65$ & & $3.73 \pm 0.53$ & & $3.21 \pm 0.53$ & \\
\hline
\end{tabular}

$(\mathrm{p}<0,05)^{*}$

\section{DISCUSSION}

According to the research findings, it was determined that the ethical climate perception of the participants was generally positive. In dimensions, ethical climate perception was found most positive in patients dimension, while most negative in physicians dimension (Table 2). According to the findings of similar studies in the literature, it is determined that ethical climate perception is generally positive, ethical climate perception is positive for patients dimension, and ethical climate perception was the most negative in physician dimension (Ghorbaniet al., 2014; Shafipour et al., 2016). Ethical climate perception is related to many factors such as job satisfaction, productivity, organizational commitment, burnout, work stress and organizational success (Thakre and Shroff, 2016; Lee al., 2018).

In this study, the ethical climate perception was statistically different in the managers dimension by gender of participants. However, he ethical climate perception level in other dimensions did not differ statistically with participants' gender (Table 3). In the study of Shafipour et al. (2016), ethical climate perception did not show a statistical difference by gender. Similarly, in the study conducted by Ekinci (2017), faculty members' perceptions of ethical climate do not differ significantly according to gender and academic title. When the findings of the research were examined in general, the ethical climate perception of the female participants was more positive than the male participants. Similarly, ethical climate perception of the female participants is more positive than the male participants in study of Karagözoğlu et al. (2014). In addition, in a study conducted by Karakuş (2018), it was determined that teachers' commitment levels were more strongly influenced by ethical leadership behaviors than men. In the study, it was thought that the positive dimension of the ethical climate perception of female participants compared to men might be due to the effect of gender on values, working life and behavior styles.

In this study, level of ethical climate perception did not differ statistically with the age of the participants (Table 3). The results of similar studies in the literature also support this finding (Karagözoğlu et al., 2014; Aydın Tükeltürk et al., 2015; Türe Yılmaz and Yildirım, 2019). According to the findings of this study, it was determined that the level of ethical climate perception did not differ by educational status of the participants (Table 3). The results of Bahcecik and Öztürk (2003) are similar to the findings of this research. The level of ethical climate perception was not statistically different according to the marital status of the participants (Table 3). The results of similar studies in the literature also support this finding (Karagözoğlu et al., 2014; Shafipour et al., 2016).In this study, ethical climate perception of the participants according to working time in hospital was significantly different in patient dimension; however there was no significant different for other dimensions (Table 3). Korkmazer et al. (2020), in the study in which nurses investigated the effect of their perceptions of hospital ethical climate on their 
performance, stated that the hospital ethical climate perception score was the highest among those who had a working period of 0-1 years in the profession and that there was a significant difference between the groups. It was thought that this result may be due to the fact that, as the professional experience of nurses increased, the patients took more responsibility for care, more respect for patient requests and increased problem solving skills. According to the results of similar studies in the literature, the perception of ethical climate did not differ according to the duration of the study in the hospital (Bahcecik and Öztürk, 2003; Aydın Tükeltürk et al., 2015).

\section{CONCLUSION}

As a result of this study, it was concluded that the ethical climate perception of the participants was generally positive. Considering the effects of ethical climate perception on employees, institutions and society, it is of great importance that the perception of ethical climate is positive. In order to have a positive perception of ethical climate, all professionals should be trained on ethical issues during their vocational education; institutions should support the ethical atmosphere, take measures to prevent unethical attitudes and behaviors and to implement sanctions on violations of ethical issues. Although this study has not been conducted with a large number of participants, it is important to reveal level of ethical climate perception in nurses working in private hospitals and whether ethical climate perception level differs according to demographic characteristics.

Limitations: The data obtained from the research is based on the self-reports of nurses participating in the study. Therefore, the research findings cannot be generalized.

Conflict of Interest: The authors declare that they have no conflict of interest.

Ethical Approval: This study was carried out upon the permissions of the Ethics Committee of Non-Interventional Research (Decision No: 2018-12/6).

\section{RE FE RENCES}

1. Allari, R.S. (2016). The relationship between hospital ethica climate, job satisfaction, and intent to turnover among nurses. Merit Research Journal of Medicine and Medical Sciences, 4(8), 392-8. $\quad$ Retrieved from https://meritresearchjournals.org/mms/content/2016/August/All ari.pdf

2. Ay, Ü., Kılıç, K.C., \& Biçer, M. (2009). İlaç ve sigorta sektörlerinde çalışan satış elemanlarının iş davranışlarının örgütsel etik iklim ile ilişkisi üzerine bir çalışma. Çukurova Üniversitesi Sosyal Bilimler Enstitüsü Dergisi, 18(2), 57-71. Retrieved https://dergipark.org.tr/en/pub/cusosbil/issue/4382/60124

3. Aydın-Tükeltürk, Ş., Şahin, D., Terlemez, B., \& Baç, A. (2015). Hospital workers' perception of ethical climate. The Journal of Academic Social Science Studies, 35, 425-37. http://dx.doi.org/10.9761/JASSS2888

4. Bahcecik, N., \& Oztürk, H. (2003). The hospital ethical climate survey in Turkey. JONA'S Healthcare Law, Ethics and Regulation, 5(4), 94-9. Retrieved from m http://journals.lww.com/jonalawbyBhDMf5ePHKav1zEoum1t QfN4a+kJLhEZgbsIHo4XMi0hCywCX1AWnYQp/IlQrHD3i3 D0OdRyi7TvSFl4Cf3 VC4/OA VpDDa8KKGKV0Ymy+78= on $12 / 21 / 2020$

5. Büte, M. (2011). Etik iklim, örgütsel güven ve bireysel performans arasındaki ilişki. Atatürk Üniversitesi İktisadi ve İdari Bilimler Dergisi, 25(1), 171-92. Retrieved from https://dergipark.org.tr/en/pub/atauniiibd/issue/2697/35633

6. Çetin, A., Güleç, R., \& Kayasandık, A.E. (2015). The effect of ethical climate perception on employees turnover intention: the mediator role of burnout. Electronic Journal of Vocational Colleges, 5(2), 18-31. Retrieved from https://dergipark.org.tr/en/pub/ejovoc/issue/45168/565502

7. Cullen, J.B., Parboteeah, K.P., \& Victor, B. (2003). The effects of ethical climates on organizational commitment: a two-study analysis. Journal of Business Ethics, 46(2), 127-41. https://doi.org/10.1023/A:1025089819456

8. DeConinck, J.B. (2011). The effects of ethical climate on organizational identification, supervisory trust, and turnover among salespeople. Journal of Business Research, 64(6), 617 24. https://doi.org/10.1016/j.jbusres.2010.06.014
9. Ekinci, Y. (2017). The Relationships between Organizational Ethical Climate and Political Behavior Perceptions of the Faculty Members. Hacettepe University Journal of Education, 32(1), 1-17. https://doi.org/10.16986/HUJE.2016023171

10. Fein, E.C., Tziner, A., Lusky, L., \& Palachy, O. (2013). Relationships between ethical climate, justice perceptions, and LMX. Leadership \& Organization Development Journal, 34(2), 147-63. https://doi.org/10.1108/01437731311321913

11. Ghorbani, A.A., Hesamzadeh, A., Khademloo, M., Khalili, S., Hesamzadeh, S., \& Berger, V. (2014). Public and private hospital nurses' perceptions of the ethical climate in their work settings, Sari city, 2011. Nursing and Midwifery Studies, 3(1), 1-6. http://dx.doi.org/10.17795/nmsjournal12867

12. Hart, S.E. (2005). Hospital ethical climates and registered nurses' turnover intentions. Journal of Nursing Scholarship, 37(2), 173-7. https://doi.org/10.1111/j.1547-5069.2005.00030.x

13. Karakus, M. (2018). The moderating effect of gender on the relationships between age, ethical leadership, and organizational commitment. Journal of Ethnic and Cultural Studies, 5(1), 74-84.

14. Karagozoglu, S., Ozden, D., \& Yıldırım, G. (2014). Intensive care nurses' perceptions of hospital ethical climate. Turkish Journal of Research \& Development in Nursing, 16(1), 34-45. Retrieved from https://dergipark.org.tr/en/pub/hemarge/issue/52734/695728

15. Korkmazer, F., Pirol, M., \& Guneysu, E. (2020). The Effect of Hospital Ethical Climate Perception of Nurses On Employee Performance. Anemon Journal of Social Sciences of Mus Alparslan University, 8(1), 163-170. https://doi.org/10.18506/anemon.523438

16. Lee, A. Y.-P., Chen, I.-H., \& Chang, P.-C. (2018). Sense of calling in the workplace: The moderating effect of supportive organizational climate in Taiwanese organizations. Journal of Management \& Organization, 24(1), 129-144. https://doi.org/10.1017/jmo.2016.16

17. Martin, K.D., \& Cullen, J.B. (2006). Continuities and extensions of ethical climate theory: a meta-analytic review. Journal of Business Ethics, 69(2), 175-94. https://doi.org/10.1007/s10551-006-9084-7

18. Moon, H.K., \& Choi, B.K. (2014). How an organization's ethical climate contributes to customer satisfaction and 
financial performance: perceived organizational innovation perspective. European Journal of Innovation Management, 17(1), 85-106. https://doi.org/10.1108/EJIM-03-2013-0020

19. Nafei, W. (2015). The influence of ethical climate on job attitudes: a study on nurses in egypt. International Business Research, 8(2), 83-99. http://dx.doi.org/10.5539/ibr.v8n2p83

20. Olson, L.L. (1988). Hospital nurses' perceptions of the ethical climate of their work setting. Image:Journal of Nursing Scholarship, 30(4), 345-9. http://10.1111/j.15475069.1998.tb01331.x

21. Schwepker, C.H. (2001). Ethical climate's relationship to job satisfaction, organizational commitment, and turnover intention in the salesforce. Journal of Business Research, 54(1), 39-52. http://10.1016/S0148-2963(00)00125-9

22. Sert, A., Elçi, M., Uslu, T., \& Şener, İ. (2014). The effects of organizational justice and ethical climate on perceived work related stress. Procedia-Social and Behavioral Sciences, 150, 1187-98. http://10.1016/j.sbspro.2014.09.134
23. Shafipour, V., Yaghobian, M., Shafipour, L., \& Heidari, M.R. (2016). Nurses' perception of the ethical climate in the iranian hospital environment. Journal of Nursing and Midwifery Sciences, 3(4), 37-43. http:// 10.18869/acadpub.jnms.3.4.37

24. Silverman, H.J. (2000). Organizational ethics in healthcare organizations: proactively managing the ethical climate to ensure organizational integrity. HEC Forum, 12(3), 202-15. http://10.1023/a:1008985411047

25. Thakre, N., \& Shroff, N. (2016). Organizational climate, organizational role stress and job satisfaction among employees. Journal of Psychosocial Research, 11(2), 469-478.

26. Türe-Yılmaz, A., \& Yıldırım, A. (2019). Ethical climate perceptions of nurses working in a university hospital. Electronic Journal of Social Sciences, 18(69), 162-76. https://doi.org/10.17755/esosder.418182 